\title{
Effect of Climate Change on Water Resources and Water Management Practices: A Review of Research Methods and Findings with Special Reference to Australia
}

\author{
Gabriel Makuei Deng Makuei \\ School of Mathematical and Geospatial Sciences, RMIT University, Melbourne, VIC 3029, Australia
}

\begin{abstract}
In this secondary research, published works on effect of climate change on water resources in other countries and in Australia were reviewed critically. Research question, objectives and assumptions were made to facilitate this study. First, methods used for such studies and their results at global level were reviewed. Then Australian specific methods of study and findings were reviewed. More commonly, both globally and in Australia, simulations using long-term real data on selected climatic scenarios of global climatic models are projected for long-term future trends. The validity and certainty of predicted occurrences depend upon the closeness of real time data with scenarios to which they are projected. Even with these limitations, projections of already rising temperatures and declining rainfall on surface water and ground water availabilities show gradual decline in water availability leading to water stress both for human communities and ecosystems The role of human-induced emissions in hastening the degradation process has also been investigated. Conserving all available water, practising efficient water consumption and prudent water policies only can provide some relief from what is inevitable.
\end{abstract}

Key words: Climate change, water resources, findings, methods, water management, review.

\section{Introduction}

The effect of climate change on water resources had been the subject of many studies. Water stress occurs when sufficient water is not available to support the population, the environment and ecosystems. Rising temperatures and decreasing rainfall, decrease river flows and ground water recharge. When water consumption exceeds replenishment, water stress occurs.

Numerous studies have been done on the effect of climate change on water resources and its impact on ecosystems and communities. Equally numerous suggestions on sustainable water management practices have also been suggested. In this paper, secondary research is done to evaluate the research findings and suggest methods of conservation and sustainable use of water.

Corresponding author: Gabriel Makuei Deng Makuei, master degree in Applied Statistics and Operation Research, associate professor at Dr. John Garang University of Science and Technology, Bor JONGLEI State, South Sudan.
The following research question is framed to facilitate the task.

\section{The Research Question}

To what extent climate change affects water resources and impacts water management practices in Australia?

The research question is split into the following objectives to focus the points of analysis better.

\section{Objectives}

(1) To critically review methods of study and findings obtained on effect of climate change on water resources in different countries and Australia.

(2) To recommend methods of water conservation and its sustainable use.

The following assumptions facilitated evaluation of usefulness of research findings.

\subsection{Assumptions}

(1) There is definite effect of climate change (natural 
or human-induced) on replenishment, storage and quality of water resources.

(2) This effect is measurable even if with varying certainties.

(3) Impact of climate change on water resources leads to changes in consumption pattern in which other factors also play their roles.

(4) The negative impact of climate change in reducing availability of water cannot be nullified. However, the adverse effects can be minimised through sustainable water management practices.

\section{Research Methodology}

Secondary research is done to collect data and information from authentic sources by literature search and reference. The information obtained is collated, classified and arranged topic-wise as per the listed objectives. The topic is divided into subtopics as per the objectives for discussions in this paper.
Generally, researchers use standard global climate models or GCMs into which selected global climate change scenarios are fed and the effects of study variables are obtained through simulation studies. The results depend on closeness of GCM model and scenarios to the real time data of the water resource sites investigated. Thus a lot of uncertainty prevails on the validity of long term projections.

In one of the early reports, Nemec and Schaake [1] undertook detailed study on response of water resources to climate variations. The relationship between climate information and design and operation of water resource systems from the paper is given in Fig. 1.

Other workers who used simulation based on GCMs and global scenarios include: Karl et al. [2], Nobre et al. [3], Arnell [4], Agrawala et al. [5], Dessai and Hulme [6], Eastham et al. [7], Arnell et al. [8], Mulligan et al. [9], Scherler et al. [10], Xu et al. [11].

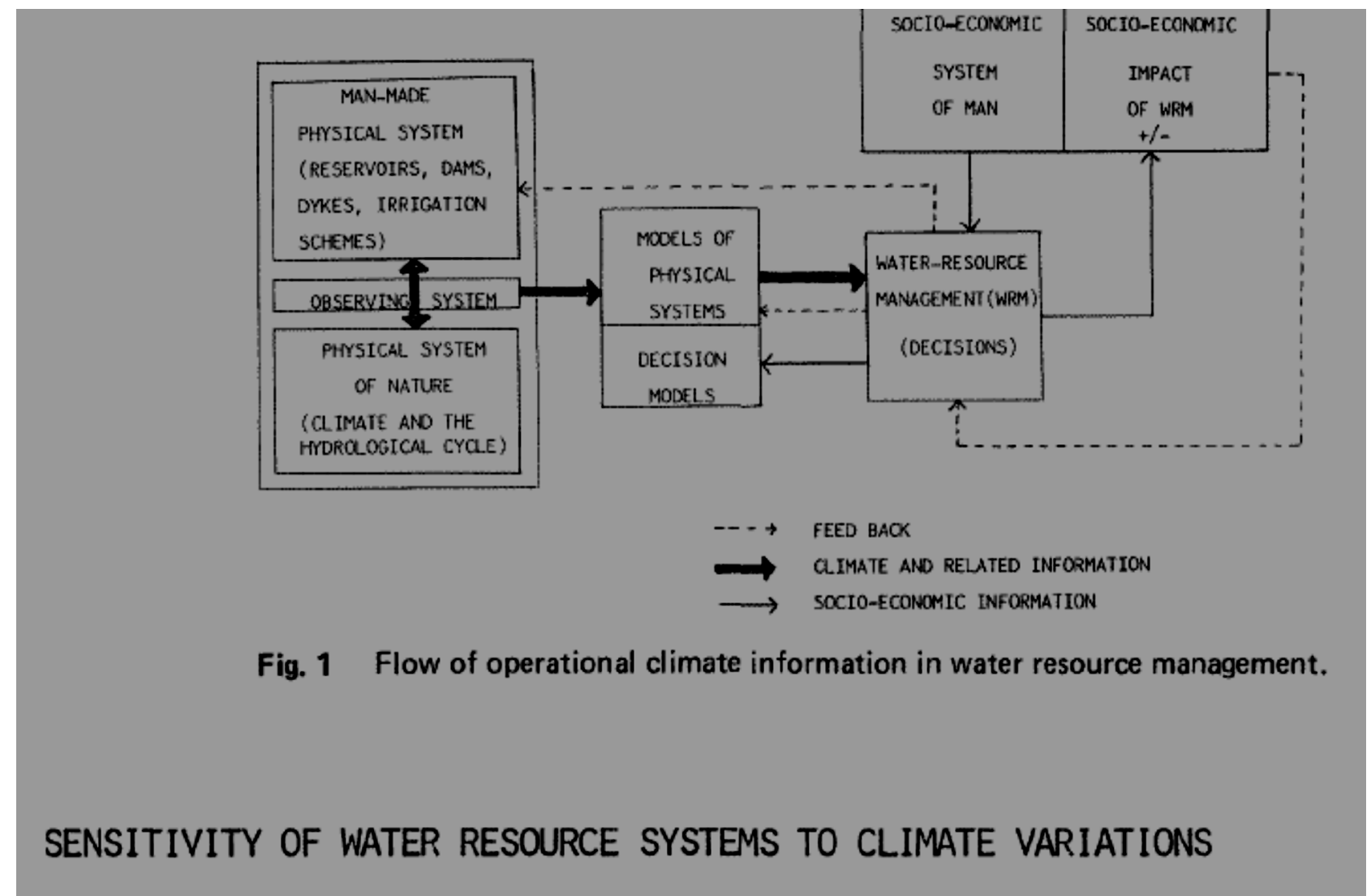

Fig. 1 Operational climate parameters in relation to water resource management [1]. 
Other methods like water balance approach [12], emission pathway analysis [13], water demand approach [14, 15], integrated approach [16], groundwater recharge approach [17], and sustainability approach [18] have also been used.

The findings and limitations of studies by these workers are discussed below. All figures and tables are given in ANNEXURE.

\section{Results and Discussions}

\subsection{Methods of Study and Findings Obtained in Other Countries}

\subsubsection{Modelling Approach}

Results of a detailed simulation study on effect of climate change and population growth on global water resources driven by different socio-economic and SRES emission scenarios were reported by Arnell [4]. When there was no climate change and at low population, about $30-40 \%$ of global population would live in water-stressed watersheds by 2025 . Proportion of people suffering under water stress increased with increasing population. There were differential effects in different areas of the world including Australia. Size of simulation, projections of population and emissions for different years may be disputable.

Amazonian deforestation causes large climate changes in terms of reduction in rainfall and evapotranspiration and increase in surface mean temperature [3]. These were associated by longer dry seasons. These differences had great impact on environment and living systems of the region.

There is considerable limitation in the current predictive techniques as well. These predictions were given by Jones [19]. Fig. 4 gives some trend projections of climate change effects.

It is difficult to relate local surface observations (daily maximum and minimum temperatures, daily rainfall, daily relative humidity etc.) to the dimensions of general circulation climatic models GCMs. Karl et al. [2] proposed a CPMS (climatologically projection by model statistics) to solve this problem. This involves principal component analysis (to reduce redundancy of predictors), canonical correlation (to develop simultaneous relationships between linear combinations of predictors) and inflated regression analysis (to relate important canonical variables to each of the surface observations) as statistical methods. The method was validated for Oregon State University data.

In Nepal, in recent decades, a warming up trend more pronounced at higher altitudes has been observed. Already in the Himalayas, glacial retreat and significant size increases of glacial lakes reducing dry season flows fed by glacier melt. Monsoon might intensify with the projected climate change inducing river flow variability. Water resources and hence the hydro-power systems are going to be affected most severely highlighting the need for urgent measures. In this case study, the recent climate trends were projected into climate change scenarios. An in-depth analysis of Nepal water resources sector was done as this sector was identified as the most severely affected one. The findings were discussed in detail in an OECD report by Agrawala et al. [5]. Possible options of climate responses and their dimensions are tabulated and discussed in the report.

Dessai and Hulme [6] applied a modelling framework to a case study analysis of water resources management in East of England. A local sensitivity analysis was performed on the elements of the framework as a one-at-a time experiment. Uncertainties of regional climate response from general circulation models and dynamic downscaling increased the sensitivity of water resources. As drier conditions are used for adaptation options considered in their plan, Anglian Water Services' Water Resource Plan is robust to climatic uncertainties.

Eastham et al. [7] discussed effect of climate change on water resources of Mekong river basin. It is the eighth largest river basin in terms of discharge from Mekong River. Mekong River includes Mekong River and its tributaries and drains covering parts of 
the six countries of Cambodia, China, Lao PDR, Myanmar, Thailand and Vietnam. Mekong River originates from Tangelo mountain range in Qinghai province of China. Its length within China is $2,161 \mathrm{~km}$. Below China, it flows through South East Asian peninsular countries to the south of Ho Chi Minh City, from where, it discharges into the South China Sea. Out of the total catchment area of about $795,000 \mathrm{~km}^{2}$, $25 \%$ is in Lao PDR, $23 \%$ in Thailand, $21 \%$ in Yunnan (China), 20\% in Cambodia, $8 \%$ in Vietnam and 3\% in Myanmar. Major catchment areas of Mekong River are given in Fig. 7. There are 18 catchment areas taken into water use account. There is wide variation in climate. It ranges from cold temperate and Tundra in Upper River Basin within China at the eastern end of Myanmar to typical tropical monsoon in Lower River Basin. At the point of its origin, the river is fed by Snowmelt. Lower Mekong is fed by run-off with very low precipitation characterized by wet and dry seasons. There are wide temporal and spatial variations of climatic parameters, land use pattern and extent of irrigation. With rapid population growth and differences in land and water use patterns, water requirement varies widely in catchment areas. These catchment areas have competing demands for water. There is water quality deterioration and salt intrusion in the delta. The authors undertook simulation studies and 4th IPCC Change (Intergovernmental Panel on Climate) methods on selected GCMs. Increase in temperature with less uncertainty and decrease in precipitation with greater uncertainty, disparity between wet and dry season precipitation in different catchment areas could be projected for future. These climatic changes caused increase in annual run-off especially during wet season. On long term, irrigation requirements are likely to increase. Varying degrees of water stress are observed in different catchment areas. Glacier melt is not a serious factor. Increase in annual run-off may reduce reliance on groundwater for irrigation. As flooding will increase, intrusion of sea water to raise the salinity levels may decrease. All these projections are highly variable for different catchment areas and seasons.

Increasing concentrations of greenhouse gases will affect temperature and rainfall and hence river flows and water resources. Based on a study on catchment areas of 21 rivers in UK, Arnell and Reynard [20] found greater variation in monthly flows than annual flows; snowfall and snowmelt were completely eliminated.

With a reference scenario of an increase in global mean temperature by $4{ }^{\circ} \mathrm{C}$ and a mitigation scenario to maintain greenhouse gas concentration around 450 ppm $\mathrm{CO}_{2}$ leading to $2{ }^{\circ} \mathrm{C}$ by 2100 , Arnell et al. [8] used a global hydrological model to study river run-off for four spatial patterns of temperature and rainfall changes. Varying degrees of change avoidance at different mitigation scenarios were observed. Thus climate policy intended to reduce water stress by limiting the rise in mean annual temperature by $50 \%$ avoiding less than half of the potential impact of climate change affecting water stress variably.

In a multi-country study on Basin Focal Project basins, Mulligan et al. [9] used multi-global circulation models of SRES scenario downscaled and extracted for each basin. Significant differences in positive and negative impacts of climate change were observed within and among basins. There was large scale uncertainty between models with regard to their impacts.

\subsubsection{Other Methods}

Effect of climate change on water resources of Lebanon was studied by Bou-Zeid and El-Fadel [12] using water balance approach. Their tables on effect of climate changes on water resources and possible technical adaptations and their effects on non-conventional water sources are reproduced in Figs. 2 and 3.

Water rights systems of California will be severely affected by climate change before 2100 due to decrease in winter precipitation and increase in temperatures leading to reduction in run-off and stream flow. This 

Research Methods and Findings with Special Reference to Australia

\begin{tabular}{|c|c|c|}
\hline Resources & Major impacted components & Potential effects \\
\hline \multirow[t]{5}{*}{ Hydrologic resources $^{a}$} & - Precipitation & - Soil moisture changes \\
\hline & - Evaporation & - Reduced groundwater recharge \\
\hline & - Transpiration & - Water shortages or surpluses \\
\hline & - Runoff & - Dam failure due to floods \\
\hline & - Recharge & - Dam storage loss due to sedimentation \\
\hline \multirow[t]{4}{*}{ Water quality ${ }^{\mathrm{a}}$} & - Water temperature & - Changes in chemical quality \\
\hline & • Water salinity & - Changes in biological quality \\
\hline & - Pollutant concentrations & - Changes in thermal quality \\
\hline & - Fauna and flora & \\
\hline \multirow[t]{5}{*}{ Aquatic systems $^{a}$} & - Streamflows & - Droughts or floods \\
\hline & - Erosion and sedimentation & - Dam failure due to floods \\
\hline & - Water levels in surface water bodies & - Dam storage loss due to sedimentation \\
\hline & - Water levels in aquifers & \\
\hline & - Water fluxes in subsurface & \\
\hline \multirow[t]{2}{*}{ Water supply ${ }^{b}$} & - Water demand per capita & - Water demand increase beyond projected levels \\
\hline & - Agricultural water demand & \\
\hline \multirow[t]{3}{*}{ Water management systems ${ }^{b}$} & - Streamflows & - Reduced water supply \\
\hline & -Water levels in surface water bodies & - Changing loads on water treatment systems \\
\hline & - Water levels in aquifers & - Changing hydropower production potential \\
\hline
\end{tabular}

Fig. 2 Impact of climate change on different types of water resources [12].

Table 11. Technical Adaptation Measures and Nonconventional Water Resources

\begin{tabular}{|c|c|c|c|}
\hline Adaptation measure & Potential benefits & Best uses & $\begin{array}{l}\text { Cost } \\
{\left[\mathrm{U}_{\text {.S. dollars/ }} /\right.} \\
\left.\left(\mathrm{m}^{3} \cdot \text { day }^{-1}\right)\right] \\
(\text { ESCWA 1999) }\end{array}$ \\
\hline Conservation & Curbs water demand increase & $\begin{array}{l}\text { Domestic, industrial, agricultural } \\
\text { demand reduction }\end{array}$ & $\begin{array}{l}\text { Cost could be negative } \\
\text { if pricing policies are } \\
\text { adopted to reduce demand }\end{array}$ \\
\hline Use of surplus winter runoff & $\begin{array}{l}\text { Collectable runoff can } \\
\text { constitute up to } 10 \% \text { of rainfall. }\end{array}$ & $\begin{array}{l}\text { Irrigation, } \\
\text { aquifer recharge }\end{array}$ & $-^{\mathrm{a}}$ \\
\hline Wastewater reclamation & All collected wastewater can be reused. & $\begin{array}{l}\text { Irrigation, } \\
\text { aquifer recharge }\end{array}$ & $0.5-1.5$ \\
\hline Seawater/brackish water desalination & Unlimited water supply & Domestic, industrial & $0.07-1.5$ \\
\hline $\begin{array}{l}\text { Rainfall enhancement by seeding clouds } \\
\text { with silver iodide crystals }\end{array}$ & $\begin{array}{l}\text { Can increase precipitation by up to } 15 \% \\
\text { in arid regions }\end{array}$ & $\begin{array}{l}\text { Irrigation, } \\
\text { Aquifer recharge }\end{array}$ & $-^{\mathrm{a}}$ \\
\hline Use of submarine springs & $\begin{array}{l}\text { Submarine springs with significant flows } \\
\text { are located along Lebanese coastal waters } \\
\text { (Ayoub et al. 2000) }\end{array}$ & $\begin{array}{l}\text { Domestic, industrial, agricultural } \\
\text { use, aquifer recharge }\end{array}$ & $-{ }^{\mathbf{a}}$ \\
\hline \multicolumn{4}{|l|}{${ }^{2}$ Not available. } \\
\hline
\end{tabular}

Fig. 3 Technical adaptations and their effects on non-conventional water resources [12].

result was obtained by Hayhoe et al. [13] in studies on impact of emissions on climate projection models. Emission pathways adopted by the government have distinct influence on these results.

Climate change not only affects water resources, but also water demand which in turn determines water use patterns. Döll [14] demonstrated that two-thirds of the global area equipped for irrigation will suffer from increased water requirements. On about half of this area, the negative impact of climate change will be more significant. The increased requirements will be largest for South Asia followed by the Middle East and then East Asia. In the highly stressed Murray-Darling basin, climate change will not affect 
irrigation requirements, but may even decrease in certain situations. However, a small increase in the irrigation requirement can cause serious problems.

In another related study, Hanjra and Qureshi [15] pointed out that global water demand has tripled supply of fresh water, which is declining since the 1950's. Increase in population will increase the number of people living in water-stressed areas from the current 0.5 billion to 3 billion by 2025 . The demand for irrigation for increased production will compete with demand from other sectors. Scarcity and declining quality of water may force some issues. Increasing competition for water from other sectors will lead to reduced use in irrigation. Increase in incidence of water-borne diseases due to poor quality. All these are forced by reduced rainfall and increased dry spells with increasing temperatures.

Increasing salinization due to increasing climatic aridity in water resources of arid and semi-arid regions was reported by Williams [18]. Climatic changes could produce measurable stress for water resources even in areas where water is in abundance now. Changes in frequency of extreme events and gradual annual changes in net water resources are possible. Some major barriers to sustainability interfere in minimizing these effects: increase in demand, wastage, poor quality and international conflicts.

In an exhaustive review on effect of climate changes on mountain water resources, Viviroli [16] contended that inadequate knowledge existed regarding this topic and more detailed regional quantification is required. An integrated approach among hydrologists, climatologists, land use specialists and policy experts is suggested for useful results. Water demand is influenced by factors other than climate change. Adaptation processes to manage water demand are called for. Problems related to effect of climate change on water resources in plains are amplified in the case of mountains. Changes in hydrology when snow or ice is involved have serious impact on the effects. Strong altitudinal gradients and exposure to solar radiation are specific to mountains. Inadequacy of observational networks affects representative data collection. Thus there are greater challenges in studying water resources in mountain regions.

The effect of melting of Himalayas was reviewed by $\mathrm{Xu}$ et al. [11]. Himalayas has the largest ice mass of ice after the Polar Regions. It is the source of 10 largest rivers of Asia. Rising temperature is reducing the volume of ice. Reduced volume of ice, rising temperature, monsoon changes, loss of soil carbon and emissions are affecting water availability in the region both in terms of amounts and seasonality leading to ecosystem boundary shifting. Environmental and social impacts of climate change increase uncertainty of water supplies and agriculture across Asia. Scherler et al. [24] questioned the conclusions of inter-governmental Panel on Climate Change about the Himalayan glaciers. Variable retreat rates and paucity of global balance data have made it difficult to make valid conclusions. The authors used remotely-sensed frontal changes and surface velocities for 2000-2008 to observe strong spatial variations in glacial behaviour related to topography and climate. They found more than $65 \%$ of glaciers in Himalayas retreating as in Tibetan plateau. Heavily debris-covered glaciers (in central Himalayas) with stagnant low gradient terminus have stable fronts. In Karakonam area, glaciers are either advancing or stable. Debris cover has emerged as an important aspect of water availability.

Ground water recharge is a critical issue as about one-third of global population depends on it. Climate change affects ground water recharge through increase in temperature and decrease in rainfall. In many areas of warming world, ground water recharge is projected to increase, but to a lesser extent than surface run-off. In the semi-arid areas, the current water stress will be aggravated due to reduced groundwater recharge. The projected rise in sea levels in 21 st century may deplete water resources for coral island communities. In 
moderate elevation coastal areas, groundwater recharge is more likely to impact recharge than tidal rise. Increase in temporal variations of river flow caused by precipitation variability and decreased snow/ice storage are the most critical aspects of surface water availability. Groundwater withdrawal needs to be lower than recharge for a sustainable groundwater management. These observations were made by Kundzewicz and Doll [17]. The observations of the authors on precipitation and groundwater recharge are given in Figs. 11 and 12.

\subsection{Australian Studies}

Apart from modelling method, type-curve method [21], greenhouse experiments gravity recovery and climate experiments [22] have also been used. The results obtained with these methods and their limitations are discussed below. There are many reports on Murray-Darling basin.

5.2.1 Modelling Approach (or Simulation Approach)

Increased frequency of high rainfall means decreased return periods. Using general circulation model (GCM), Whetton et al. [23] predicted such events to increase flooding. But applicability of its quantitative assessment in real situation could not be established. An off-line soil water balance model was used to feed time series data on rainfall and potential evaporation and determine sensitivity of soil water regime to changes in rainfall and temperature. This sensitivity analysis was linked to scenarios of regional climate changes derived from greenhouse simulations of five GCMs. Results showed that significant drought could occur only in Southern Australia. Uncertainty on direction of change in soil water regime at all sites and for all seasons makes explanation difficult.

Modelling studies on the impact of climate changes on extreme flow events, soil moisture and water availability were done by Schreider et al. [24]. These studies were done on five rivers contributing to Ovens Basin and nine rivers of Goulburn basin. These two have a total catchment area of about $6,500 \mathrm{~km}^{2}$. Simulation tests were done on the models over the entire period of observation for all the 14 catchments. Observed and simulated results were similar for stream flow data.

Effects of low rainfall in South-Eastern Australia during 1997-2006 were analysed by Murphy and Timbal [25]. Most of the decline in rainfall occurred during March-May (autumn) season. Apart from hemispherical and local circulations, increased emissions also could contribute towards the observed climate change. The droughts have caused severe water scarcity in the region affecting agricultural and human activities significantly.

There had been $50 \%$ reduction in dam inflows in Southwest Western Australia since the 1970's. This is due to climate change. These impacts led to the formation of Indian Ocean Climate Initiative in 1998 for coordination of works done by various agencies in this region. Bates et al. [26] reviewed the scientific findings and their impact on the policy development in Australia. The annual mean temperature rose by $0.15{ }^{\circ} \mathrm{C}$ per decade. Rainfall in the region declined (Fig. 5) especially with respect to early winter rains. However, there was no decline in late winter rains. There was $14 \%$ decline in mean total rainfall during 1975-2004 compared to 1925-1974. High rainfall years have practically disappeared. One of the main consequences of this was reduction in surface water available for storage. As shown in Fig. 6 the average inflow into the regional integrated water supply system progressively declined from 338 GL during 1911-1974 to 177 GL during 1975-1996, 114 GL from 1997-2005 and 82 GL during 2001-2006. The absence of very high peaks since the 1970's is notable. Increasing death rates of Eucalyptus trees in the area due to water stress occurs almost in parallel. Inherent natural fluctuations in the system coupled to ocean atmosphere, greenhouse gas emissions and land clearing are indicated as the causes for these climate changes. Future climatic changes and their effects are 
uncertain due to the problems with assumptions made in climatic modelling. The findings of the Initiative led to the formulation of a state water strategy in 2003. Source development plans for 2005-2050 consists of sea water desalination, treated waste water recycling, better management of catchment areas and water trading. A greenhouse strategy to reduce emissions has also been evolved. Future studies will focus on potential risks to agriculture, forestry, biodiversity, health tourism, coastal ecology and infrastructure.

During the hottest Australian drought of 2001-2007, inflow into Murray-Darling river system was at an all-time low. Annual total inflow was more sensitive to rainfall over southern areas of the basin, where the annual rainfall was the lowest during 2001-2007. Cai and Cowan [27] discovered a relationship between inflow variations and temperature fluctuations (not related to rainfall) during the austral winter and spring.
A rise in temperature by $1{ }^{\circ} \mathrm{C}$ led to a decrease in annual inflow by $15 \%$. Rise in temperature is ascribed to greenhouse effects. In another study on Murray-Darling basin, Austin et al. [28] used the biophysical capacity to change model with climate change scenarios two CSIRO regional climate models. Up to $25 \%$ reduction in mean annual rainfall corresponding with a similar increase in evapotranspiration was observed by 2070 . This leads to significant decreases in annual run-offs. Salt concentration within the basin increased. Average annual rainfall in catchment areas was decreased by $13-21 \%$ along with these results.

Median projections of Murray-Darling showed more frequent droughts affecting irrigated agriculture significantly. Spatial and temporal changes in water availability were noticed [29]. Suitable mitigation efforts were recommended.

Table 2 Predicted trends in global precipitation, runoff and per capita water resources based on the output from HadCM2GHG, with some additions from HadCM2SUL.

\begin{tabular}{|c|c|c|c|c|}
\hline & Present & $2020 \mathrm{~s}$ & $2050 \mathrm{~s}$ & $2080 \mathrm{~s}$ \\
\hline Precipitation*(HadCM2GHG) & & $+3.0 \%$ & $+4.5 \%$ & $+6.25 \%$ \\
\hline Precipitation* (HadCM2SUL) & & $+2.0 \%$ & $+2.5 \%$ & $+4.2 \%$ \\
\hline Runoff (HadCM2) ${ }^{*}$ & & $+2.9 \%$ & $+4.0 \%$ & $+6.5 \%$ \\
\hline Additional runoff $\left(\mathrm{km}^{3}\right)$ (HadCM2GHG) & & 1126 & 1553 & 2524 \\
\hline \multicolumn{5}{|l|}{ Population increase } \\
\hline Population in millions ${ }^{\ddagger}$ & 5266 & 8121 & 9759 & 10672 \\
\hline$\%$ increase & - & $+54 \%$ & $+85 \%$ & $+103 \%$ \\
\hline \multicolumn{5}{|l|}{ Per capita resources } \\
\hline Due to population increase only & & $-35 \%$ & $-46 \%$ & $-51 \%$ \\
\hline $\begin{array}{l}\text { Due to population increase + climate } \\
\text { change }\end{array}$ & & $-34 \%$ & $-44 \%$ & $-48 \%$ \\
\hline \multicolumn{5}{|l|}{ Population in stress ${ }^{+}$} \\
\hline $\begin{array}{l}\text { Billions using }>20 \% \text { of available water } \\
\text { resources (AWR) }\end{array}$ & 1.9 & 5.1 & 5.9 & 6.5 \\
\hline$\%$ increase & & $+168 \%$ & $+211 \%$ & $+242 \%$ \\
\hline extra millions due to climate change $\mathrm{e}^{\S}$ & & - & 66 & - \\
\hline $\begin{array}{l}\text { Billions using }>40 \% \text { of available water } \\
\text { resources (AWR) }\end{array}$ & 0.454 & 2.4 & 3.1 & 3.6 \\
\hline$\%$ increase & & $+429 \%$ & $+583 \%$ & $+693 \%$ \\
\hline extra millions due to climate change ${ }^{\dagger}$ & & 26 & $117^{(+)} 170^{(5)}$ & 98 \\
\hline
\end{tabular}

Fig. 4 Trend projections of climatic global climatic change effects [19]. 


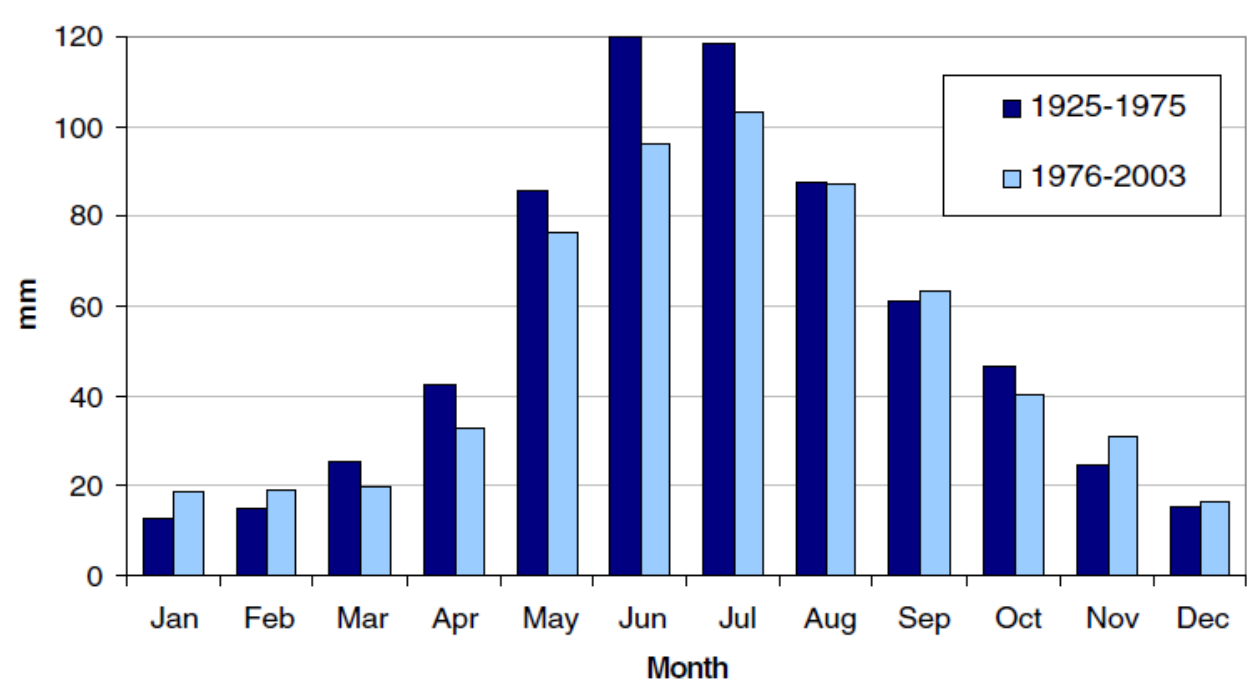

Fig. 5 Changes in rainfall pattern in south-western Australia [26].

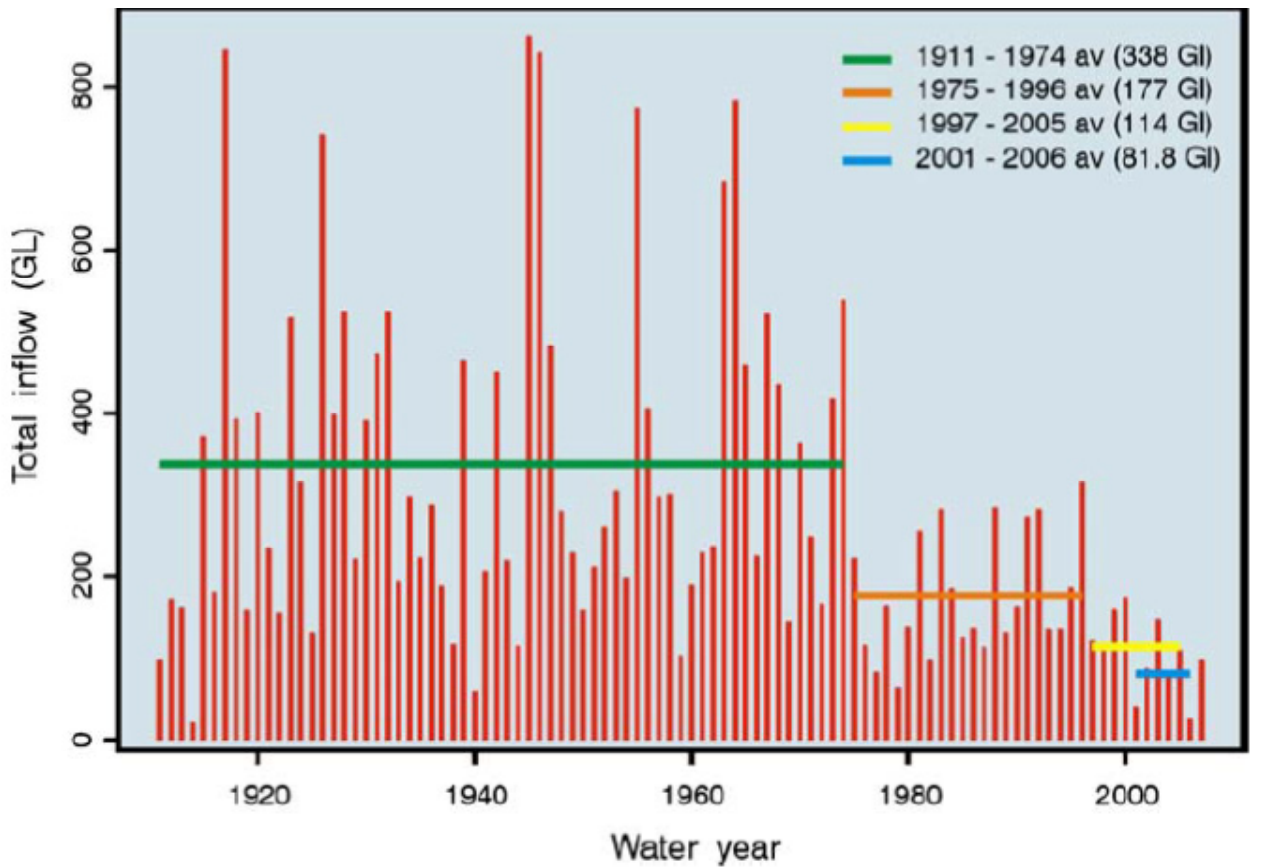

Fig. 6 May to April annual inflows into the integrated water supply system for 1900-2006 [26].

In the natural environment of Australia is bestowed with many temporary and permanent wetlands. Climate change has modified the water regime and increased the salinity levels. Extended droughts due to lower rainfall and higher temperatures have affected the natural hydrological systems in Southern Australian as observed by Nielsen and Brock [30].

In a scenario modelling using global climate models,
Barron et al. [31] studied the effect of decreasing rainfall and increasing temperature in the case of South-Western Australian surface and ground water resources. The authors used 15 models under three global warming scenarios. Under dry future scenario, the river flow rate would reduce by 2 months per year. This will cause significant stress on economic communities. In addition, some rivers may have a four 
months period of no-flow. Ground water dependent vegetation will be at high risk in about one-fifth of the area. Increased ground water abstraction will seriously affect water-dependent ecosystems. Thus the effect of climate change is not uniform across the region. The great threat to water-dependent ecosystems is strongly indicated. The authors point out the need for good water management practices in at least most seriously threatened six out of the 13 catchment areas and areas of high ground water abstraction of the region.

Léger et al. [32] rated Kakadu National Park as vulnerable to climatic changes. Using modelling under climatic change scenarios, they found salt water intrusion to be threatening fresh water ecosystem within the south Alligator river system. This happens due to increased tidal pressure on the dendritic channels and increased levee overtopping. There were significant changes in the number of wet and dry days. The frequency, duration and extent of large floods were also altered.

In another study on South-Western Australian region, Silberstein et al. [33] used computer simulations of run-off from 13 major fresh and brackish river basins. The data were obtained from 15 global climate models using three global warming scenarios. Computer simulation provided an efficient methodology to analyse the impact over large regions. Rainfall-runoff models were calibrated using stream flow data of 1975-2007 collected from 106 gauges set up in the region. All the models and all the scenarios projected an average of $8 \%$ decline in rainfall resulting in an average of $25 \%$ decline in run-off. The impact of driest month on these reductions was severe. Proportional decline in run-off was the greatest in northern region. Volumetric decline in run-off was the greatest in the wetter southern basins. Stream flows into major water supply reservoirs of the region declined by more than $50 \%$ concomitant with about $16 \%$ reduction in rainfall since the 1970 's. The authors warn that the declining trends will continue challenging the current water management practices.
Warming of air and sea temperatures are significant natural and man-made effects. Lough and Hobday [34] noted the higher ocean warming around than global average around Australia. Drier winters in Southern and South-Western and Western Australia can be due to human-induced climate change. Even if annual rainfall does not decrease, the effect of temperature in increasing evapotranspiration will reduce available water. The authors recommend sustainable water management practices.

The climate-change induced land use and land cover change were studied by Mcalpine et al. [35]. The observations highlighted the importance of prudent natural resources management.

\subsubsection{Other Methods}

Hughes [21] using type curve method for sub-surface thermal regime for ground water fluxes in terms of step increases.

Taniguchi et al. (1999) demonstrated the effect of forest clearing for agriculture on Collie River Basin in South-West Australia.

Two different methods were used (Chiew et al., $1995)$ in studies on the effects of climate change on run-off and soil moisture in 28 Australian catchment areas. In one method, a range of arbitrary changes in temperature and precipitation were applied to calibrated rainfall-runoff models to estimate the sensitivity of runoff and soil moisture to potential climatic changes. In the second method, results from the five global climatic model enhanced greenhouse experiments were analysed to obtain regional scenarios of climatic change which were used for estimation of the range of plausible run-off and soil moisture changes for the years 2030 and 2070. In the sensitivity analysis, precipitation changes always led to amplification in the run-off, its factor being higher for drier catchment areas. While in wet catchments, precipitation changes did not affect soil moisture changes, in dry regions, changes in soil moisture were greater than changes in rainfall. Temperature changes did not affect run-off and soil moisture. In the simulations using GCM 


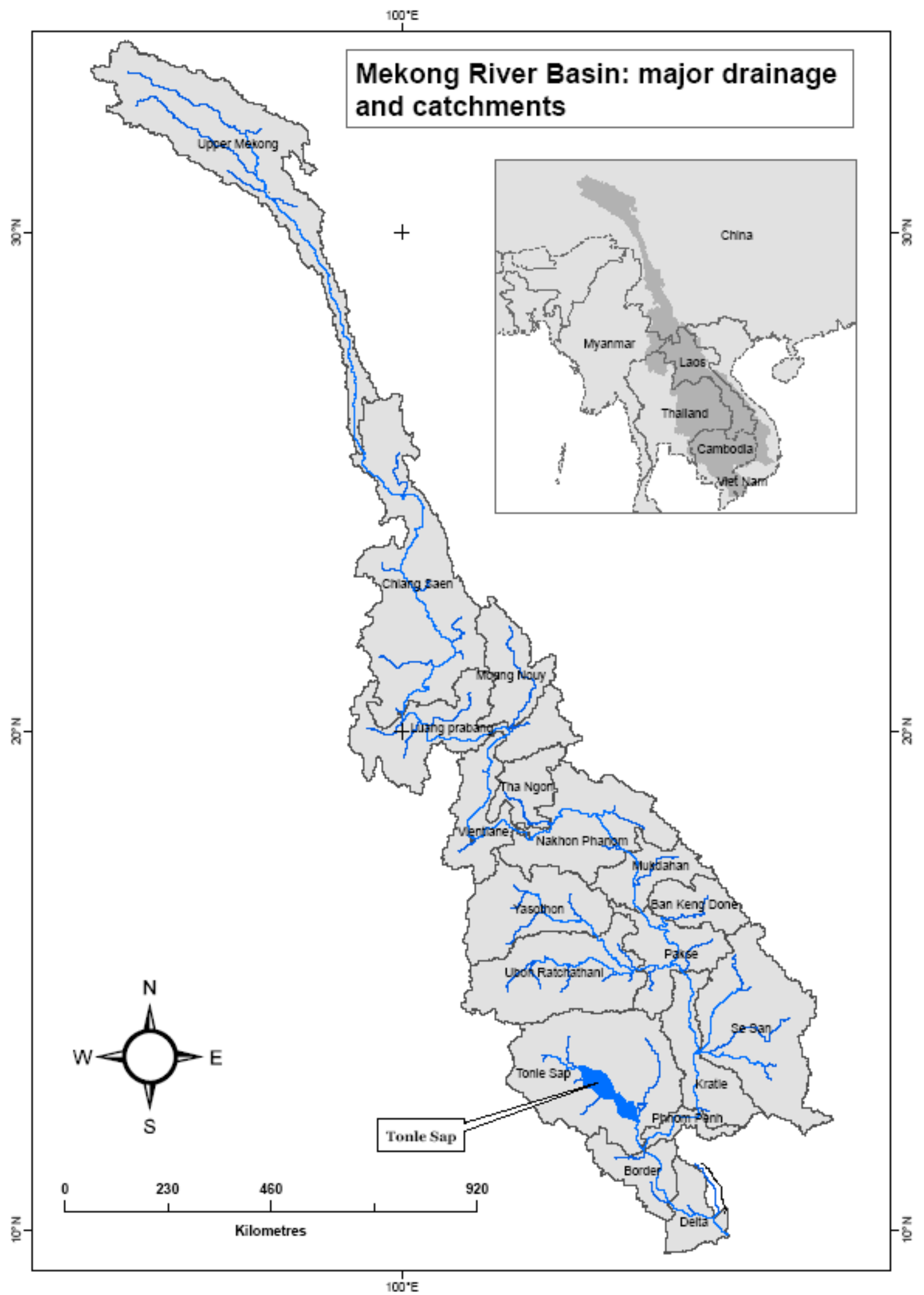

Fig. 7 Major catchment areas of Mekong river basin [7]. 
scenarios, about $25 \%$ increase in annual run-off was reached for wet catchment areas in tropical catchments near north-east coast, $10 \%$ increase for Tasmanian catchments and 35\% decrease for South Australian Gulf catchments by 2030. These effects of climate change on run-off indicated the need for significant planning response.

In another detailed study, Leblanc et al. [22] used a combination of GRACE (gravity recovery and climate experiment) and modelled hydrological data for in situ studies for basin-scale observations in Murray-Darling. Propagation of water deficit was found to occur through hydrological cycle. This gave rise to different types of droughts. Rapid drying up of soil moisture and surface water storage (Fig. 10) to a near stable level occurred about two years after the drought of 2001 started and lasted till 2003. There was almost complete drying up of surface water resources due to this drought. The reduction in ground water levels persisted even six years after the start of drought. The hydrological drought continued even though average rainfall returned in 2007, as shown in Fig. 9. The cumulative rainfall deficit for 2001-2006 given by the authors is reproduced in Fig. 8. Most severe drought was observed in the northern and south-south eastern regions.

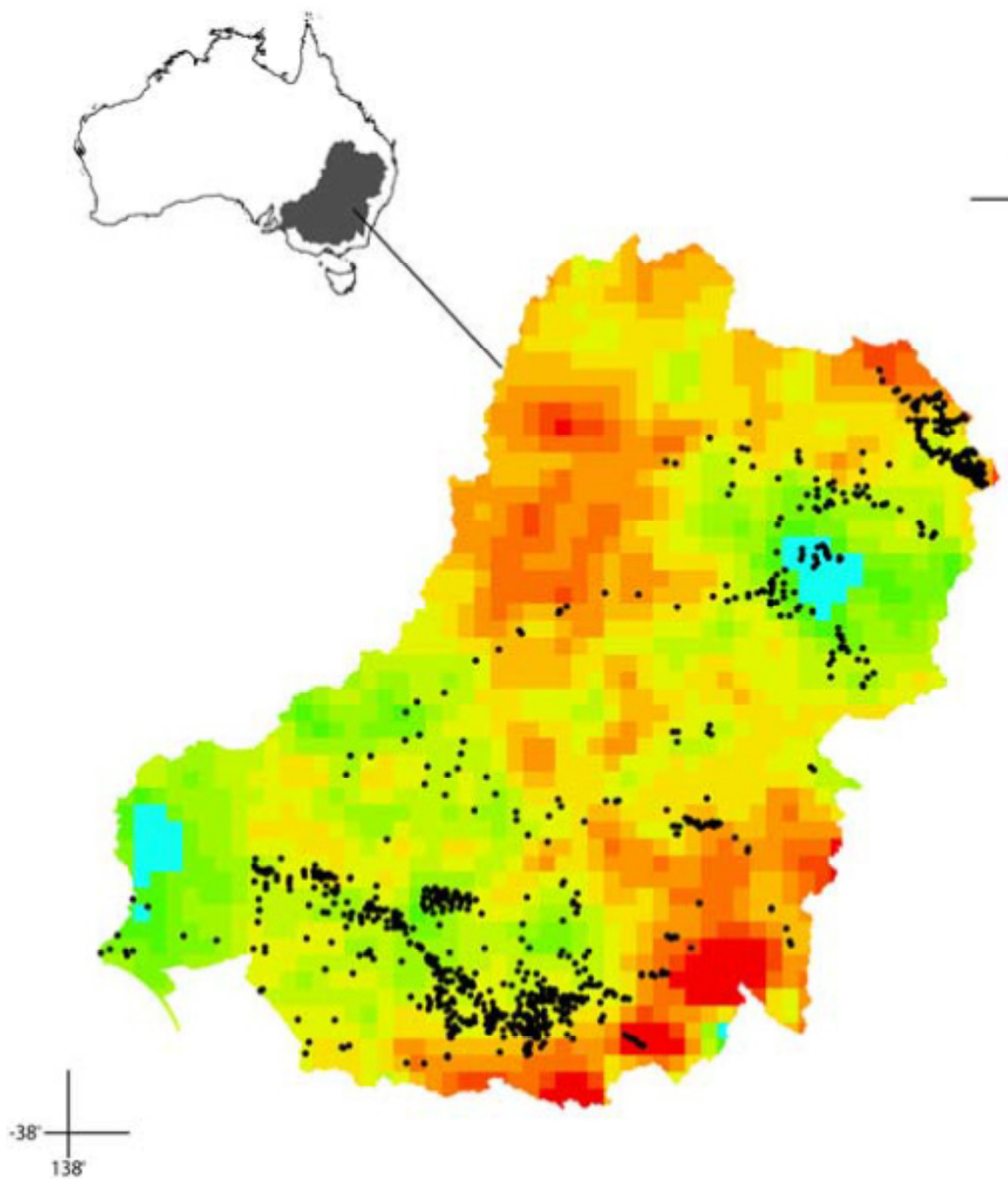

Cumulative (2001 to 2006) rainfall deviation to the long-term mean (1900 to 2006) in $\mathrm{mm}$.

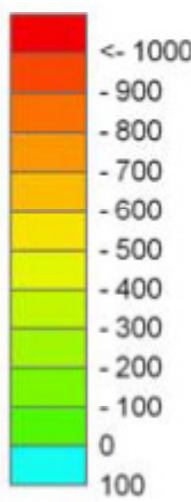

- Observation bores

Fig. 8 The cumulative rainfall deficit for 2001-06 [22]. 

Research Methods and Findings with Special Reference to Australia

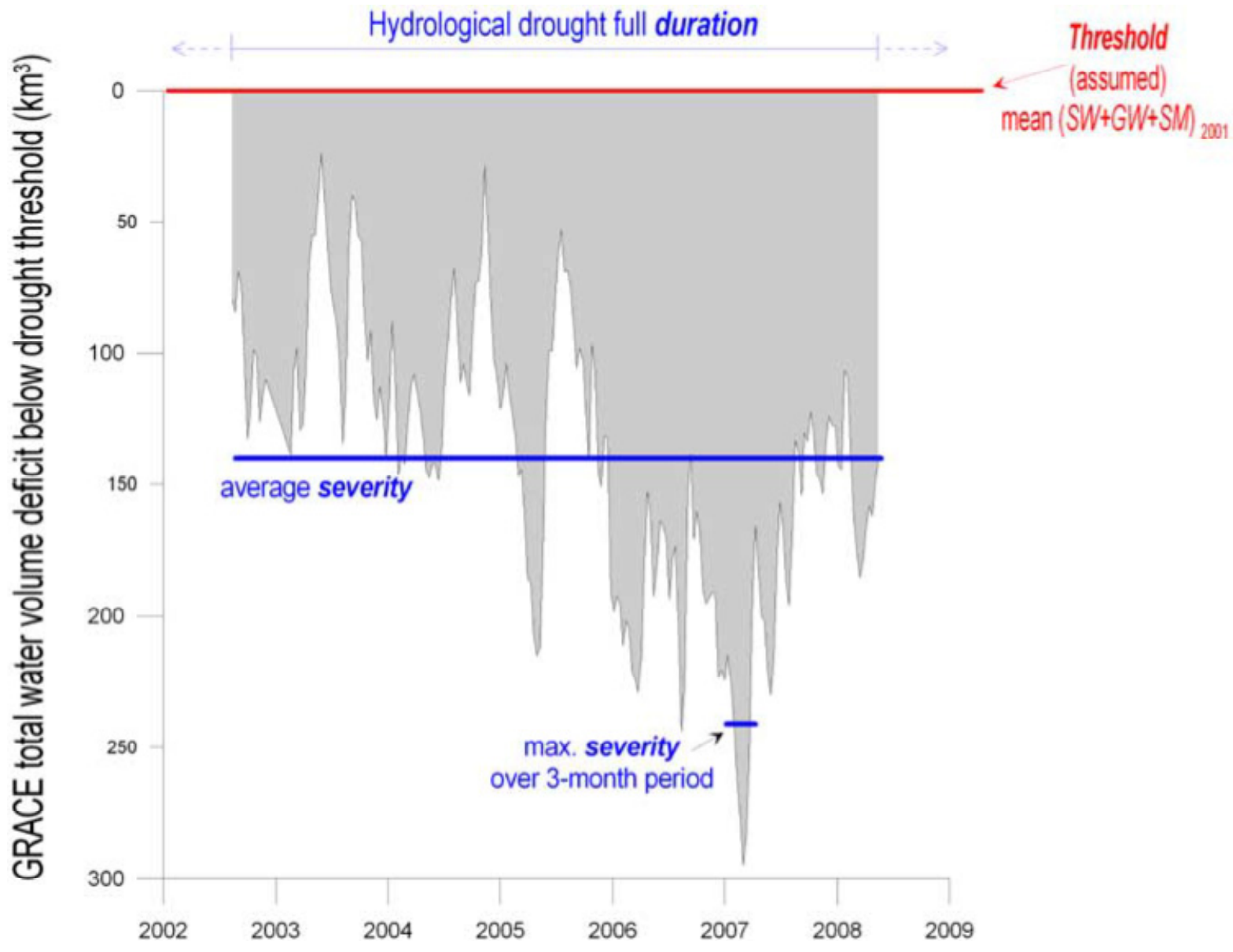

Fig. 9 The severity of multi-year drought during 2002-2009 [22].

W04408

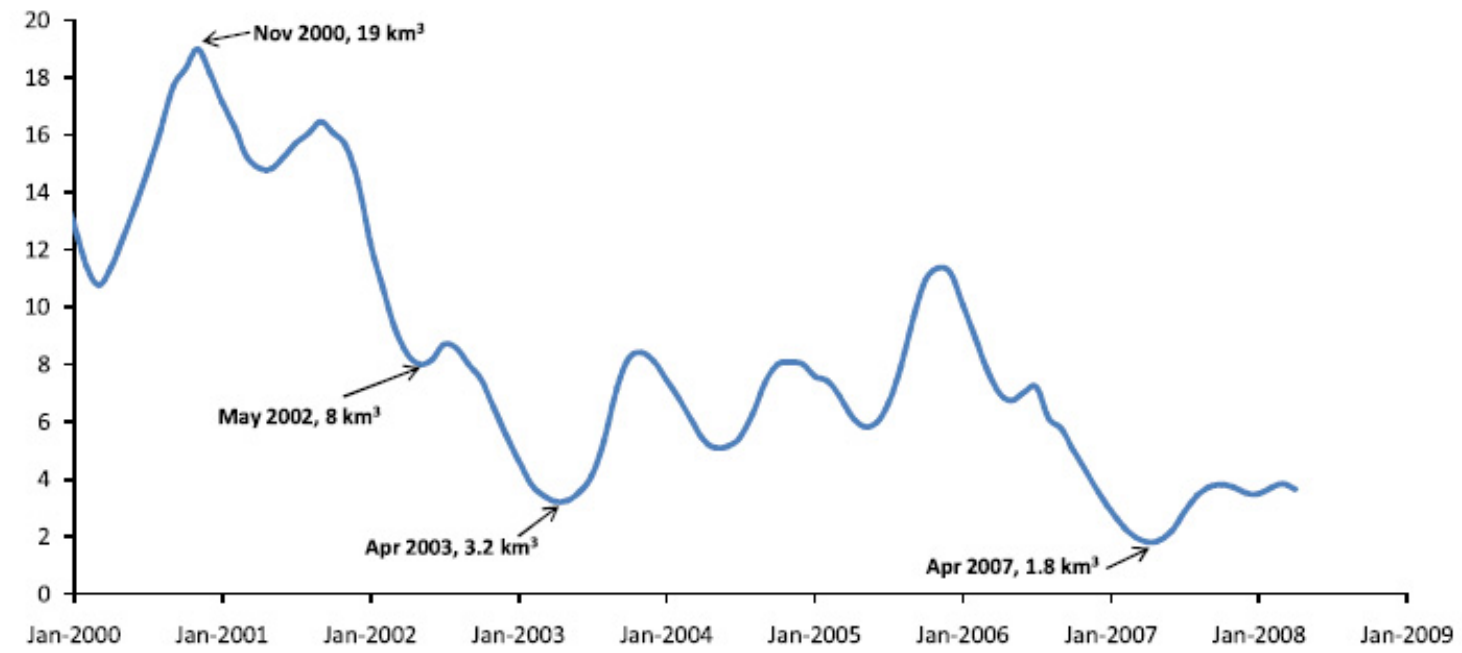

Figure 2. Change in surface water storage in the infrastructure system (reservoirs, lakes, weirs, and inchannel storage) of the Murray-Darling Basin.

Fig. 10 Surface water storage changes in all storage systems [22]. 
Effect of Climate Change on Water Resources and Water Management Practices: A Review of Research Methods and Findings with Special Reference to Australia
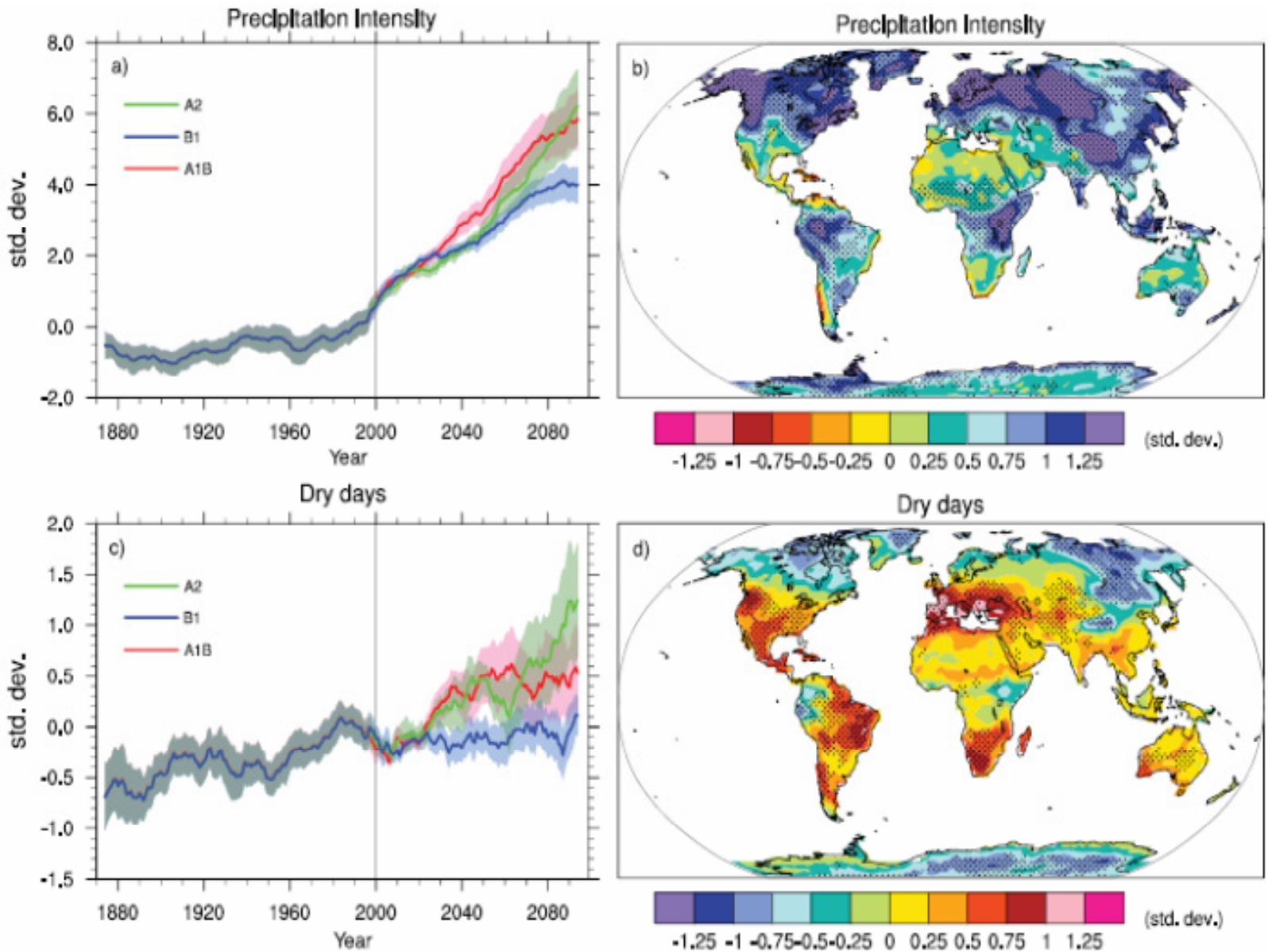

Fig. 11 Global changes in extremes of precipitation and dry days over 20 years comparisons [17].

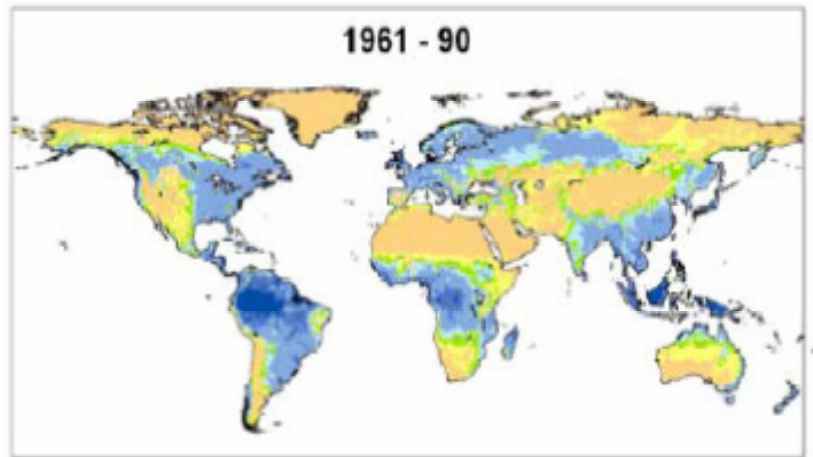

\section{Average annual groundwater recharge 1961-90}

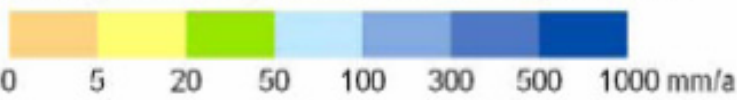

Percent change of groundwater recharge

between $1961-90$ and the $2050 \mathrm{~s}$

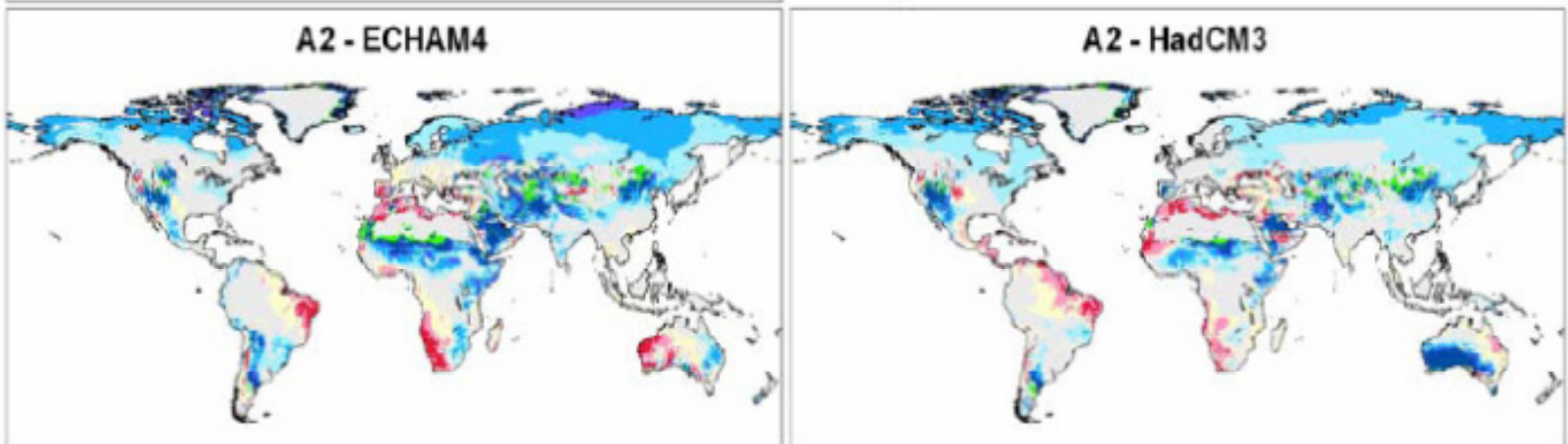

Fig. 12 long term average annual diffuse groundwater recharge over 30 years [17]. 


\section{Conclusions}

Of the several methods used for studying effect of climate change on water resources and water management practices, modelling methods are more popular and more precise. GCM (general circulation model) and scenario modelling are particularly favored. However, these models are reliable only to the extent of relationship of the data used with the actual situation. Methods used in Australia are similar to those used in other countries.

The urgent need for developing a water policy for Australia was reiterated by Crase [36]. According to a National Plan for Water Security proposed by Howard government in January 2007, greater control of the federal government on water resource management was envisaged. The federal government had a plan to contribute \$A10 billion in Murray-Darling basin as one of the initial steps. However, as states wanted to protect their exclusive water rights, this plan could not be implemented. Positive and negative forces determine the outcomes of reforms. The declining water availability due to climate change is aggravated by the still continuing large uses for irrigation. Water resources problem of Australia is not due to lack of water as such. It is more due to the imbalance between water availability controlled by irregularity of rainfall and current use pattern. Large-scale irrigated agriculture consumes a large portion of available water. The level of water extraction from Australian rivers is increasingly higher than its replenishing capacity due to the climate change affecting water resources seriously. Long term predictions do not support continuance of current use pattern from river basins such as Murray-Darling. There is steady increase in diversion of water use from Murray-Darling basin. The federal government has been increasingly involved in policies of water extraction from basins like Murray-Darling and to provide financial assistance. Policies set by National Water Initiative proposed that any reduction in consumptive use due to climate change and natural calamities is to be borne by the user. An all-acceptable national water policy still evades Australia.

All the assumptions were validated in this secondary study.

\section{Recommendations}

Based on the above conclusions, the following recommendations are given.

(1) Focus on water conservation. Without having efficient water conservation in place, sustainable consumption is impossible.

(2) Determine exact agricultural needs of water based on food needs of increasing population and cropping details required to produce that food. Development of drought tolerant crops, conservation of soil moisture in cultivated land and use of efficient irrigation systems like drip irrigation are some possibilities yet to be fully exploited.

(3) Similarly determine other requirements and ration the water supplies according to conserved water.

(4) Encourage ground water recharge on a large scale.

\section{References}

[1] Nemec, J., and Schaake, J. 1982. "Sensitivity of Water Resource Systems to Climate." Hydrological Sciences Journal 27 (3): 327-43. Available at: HYPERLINK http://iahs.info/hsj/270/hysj_27_03_0327.pdf; http://iahs.info/hsj/270/hysj_27_03_0327.pdf [Accessed 19 March 2012].

[2] Karl, T. R. et al. 1990. "A Method of Relating General Circulation Model Simulated Climate to the Observed Local Climate. Part I: Seasonal Statistics." Journal of Climate 3 (10): 1053-79. Available at: HYPERLINK http://journals.ametsoc.org/doi/abs/10.1175/1520-0442(1 990)003\%3C1053\%3AAMORGC\%3E2.0.CO\%3B2; http://journals.ametsoc.org/doi/abs/10.1175/1520-0442(1 990)003\%3C1053\%3AAMORGC\%3E2.0.CO\%3B2 [Accessed 21 March 2012].

[3] Nobre, C. A., Sellers, P. J., and Shukla, J. 1991. "Amazonian Deforestation and Regional Climate Change." Journal of Climate Change 4 (10): 957-88. Available at: HYPERLINK http://journals.ametsoc.org/doi/abs/10.1175/1520-0442(1 

Research Methods and Findings with Special Reference to Australia

991)004\%3C0957\%3AADARCC\%3E2.0.CO\%3B2;

http://journals.ametsoc.org/doi/abs/10.1175/1520-0442(1

991)004\%3C0957\%3AADARCC\%3E2.0.CO\%3B2

[Accessed 19 March 2012].

[4] Arnell, N. W. 2004. "Climate Change and Global Water Resources: SRES Emissions and Socio-Economic Scenarios." Global Environmental Change 14 (1): 31-52. Available at: HYPERLINK http://www.undp-adaptation.org/library/files/Arnell_2004 _CCWater.pdf;

http://www.undp-adaptation.org/library/files/Arnell_2004 _CCWater.pdf [Accessed 19 March 2012].

[5] Agrawala, S. et al. 2003. Development and Climate Change in Nepal: Focus on Water Resources and Hydropower.

COM/ENV/EPOC/DCD/DAC(2003)1/FINAL. OECD.

[6] Dessai, S., and Hulme, M. 2007. "Assessing the Robustness of Adaptation Decisions to Climate Change Uncertainties: A Case Study on Waterresources Management in the East of England." Global Environmental Change 17 (1): 59-72. Available at: HYPERLINK

http://www.sciencedirect.com/science/article/pii/S095937 8006000914;

http://www.sciencedirect.com/science/article/pii/S095937 8006000914 [Accessed 23 March 2012].

[7] Eastham, J. et al. 2008. Mekong River Basin Water Resources Assessment: Impacts of Climate Change. Water for a Healthy Country Flagship Report series. CSIRO.

[8] Arnell, N. W., Vuuren, D. P. V., and Isaac, M. 2011. "The Implications of Climate Policy for the Impacts of Climate Change on Global Water Resources." Global Environmental Change 21 (2): 592-603. Available at: HYPERLINK

http://www.sciencedirect.com/science/article/pii/S095937 8011000161;

http://www.sciencedirect.com/science/article/pii/S095937 8011000161 [Accessed 23 March 2012].

[9] Mulligan, M. et al. 2011. "The Nature and Impact of Climate Change in the Challenge Program on Water and Food (CPWF) Basins." Water International 36 (1 Special Issue: Water, Food and Poverty in River Basins, Part 2: Cross-Basin Analysis and Synthesis): 96-124. Available at:

HYPERLINK http://www.tandfonline.com/doi/abs/10.1080/02508060.2 011.543408;

http://www.tandfonline.com/doi/abs/10.1080/02508060.2 011.543408 [Accessed 27 March 2012].

[10] Scherler, D., Bookhagen, B., and Strecker, M. R. 2011. "Spatially Variable Response of Himalayan Glaciers to Climate Change Affected by Debris Cover." Nature
Geoscience 4 (3): 156-59. Available at: HYPERLINK http://geokomm.de/media/de/ScherlerPaper.pdf; http://geokomm.de/media/de/ScherlerPaper.pdf [Accessed 26 March 2012].

[11] Xu, J. et al. 2009. "The Melting Himalayas: Cascading Effects of Climate Change on Water, Biodiversity, and Livelihoods." Conservation Biology 23 (3): 520-30. Available at: HYPERLINK http://onlinelibrary.wiley.com/doi/10.1111/j.1523-1739.2 009.01237.x/full;

http://onlinelibrary.wiley.com/doi/10.1111/j.1523-1739.2 009.01237.x/full [Accessed 26 March 2012].

[12] Bou-Zeid, E., and El-Fadel, M. 2002. "Climate Change and Water Resources in Lebanon and the Middle East." Journal of Water Resources Planning and Management 128 (5): 343-55. Available at: HYPERLINK http://infoscience.epfl.ch/record/91091/files/Bou-Zeid\%2 0and\%20El-Fadel\%20-\%202002\%20-\%20JWRPM\%20$\% 20$ improved $\% 20$ graphics.pdf;

http://infoscience.epfl.ch/record/91091/files/Bou-Zeid\%2 0and\%20El-Fadel\%20-\%202002\%20-\%20JWRPM\%20\%20improved\%20graphics.pdf [Accessed 19 March 2012].

[13] Hayhoe, K. et al. 2004. "Emissions Pathways, Climate Change, and Impacts on California." Proceedings of the National Academy of Sciences of the United States of America 101 (34): 12422-27. Available at: HYPERLINK http://www.ncbi.nlm.nih.gov/pmc/articles/PMC514653/; http://www.ncbi.nlm.nih.gov/pmc/articles/PMC514653/ [Accessed 23 March 2012].

[14] Döll, P. 2002. "Impact of Climate Change and Variability on Irrigation Requirements: A Global Perspective." Climate Change 54 (3): 269-93. Available at: HYPERLINK

https:/www.uni-frankfurt.de/fb/fb11/ipg/ag/dl/f_publikat ionen/2002/doell_ClimaticChange2002_irrigation.pdf; https://www.uni-frankfurt.de/fb/fb11/ipg/ag/dl/f_publikat ionen/2002/doell_ClimaticChange2002_irrigation.pdf [Accessed 21 March 2012].

[15] Hanjra, M., and Qureshi, M. E. 2010. "Global Water Crisis and Future Food Security in an Era of Climate Change." Food Policy 35 (5): 365-77. Available at: HYPERLINK

http://bwl.univie.ac.at/fileadmin/user_upload/lehrstuhl_in d_en_uw/lehre/ss11/Sem_Yuri/Water-food.pdf; http://bwl.univie.ac.at/fileadmin/user_upload/lehrstuhl_in d_en_uw/lehre/ss11/Sem_Yuri/Water-food.pdf [Accessed 26 March 2012].

[16] Viviroli, D. E. A. 2010. "Climate Change and Mountain Water Resources: Overview and Recommendations for Research, Management and Politics.” Discussion paper. Hydrology and Earth System Sciences. 
[17] Kundzewicz, Z. W., and Doll, P. 2009. "Will Groundwater Ease Freshwater Stress under Climate Change? Hydrological Sciences Journal 54 (4): 665-75. Available at:

HYPERLINK http://www.geo.uni-frankfurt.de/ipg/ag/d1/f_publikatione n/2009/Kundzewicz_doell_HSJ_2009_climate_and_grou ndwater_hysj_54_4_665.pdf;

http://www.geo.uni-frankfurt.de/ipg/ag/dl/f_publikatione n/2009/Kundzewicz_doell_HSJ_2009_climate_and_grou ndwater_hysj_54_4_665.pdf [Accessed 27 March 2012].

[18] Williams, W. D. 1999. "Salinisation: A Major Threat to Water Resources in the Arid and Semi-Arid Regions of the World." Lakes \& Reservoirs: Research \& Management 4 (3-4): 85-91. Available at: HYPERLINK http://onlinelibrary.wiley.com/doi/10.1046/j.1440-1770.1 999.00089.x/references;

http://onlinelibrary.wiley.com/doi/10.1046/j.1440-1770.1 999.00089.x/references [Accessed 20 March 2012].

[19] Jones, J. A. A. 1999. "Climate Change and Sustainable Water Resources: Placing the Threat of Global Warming in Perspective." Hydrological Sciences Journal 44 (4): 541-57. Available at: HYPERLINK http://www.iahs.info/hsj/440/hysj_44_04_0541.pdf; http://www.iahs.info/hsj/440/hysj_44_04_0541.pdf [Accessed 20 March 2012].

[20] Arnell, N. W., and Reynard, N. S. 1996. "The Effects of Climate Change due to Global Warming on River Flows in Great Britain." Journal of Hydrology 183 (3-4): 397-424. Available at: HYPERLINK http://www.sciencedirect.com/science/article/pii/0022169 495029508;

http://www.sciencedirect.com/science/article/pii/0022169 495029508 [Accessed 23 March 2012].

[21] Hughes, L. 2003. "Climate change and Australia: Trends, Projections and Impacts." Austral Ecology 28 (4): 423-43. Available at: HYPERLINK http://www.edo.org.au/edonsw/site/pdf/subs/climate\%20c hange $\% 20$ review.pdf;

http://www.edo.org.au/edonsw/site/pdf/subs/climate $\% 20 \mathrm{c}$ hange\%20review.pdf [Accessed 3 March 2012].

[22] Leblanc, M. J. et al. 2009. "Basin-Scale, Integrated Observations of the Early 21st Century Multiyear Drought in Southeast Australia." 45 (4): 10. ID04408. Available at: HYPERLINK http://rses.anu.edu.au/geodynamics/tregoning/34.pdf; http://rses.anu.edu.au/geodynamics/tregoning/34.pdf [Accessed 26 March 2012].

[23] Whetton, P. H., Fowle, A. M., Haylock, M. R., and Pittock, A. B. 1993. "Implications of Climate Change due to the Enhanced Greenhouse Effect on Floods and Droughts in Australia." Climate Change 25 (3-4): 289-317. Available at: HYPERLINK http://www.springerlink.com/content/kq101124n30hj4k5/; http://www.springerlink.com/content/kq101124n30hj4k5/ [Accessed 3 March 2012].

[24] Schreider, S. Y., Jakeman, A. J, Pittoc, A. B., and Whetton, P. H. 1996. "Estimation of Possible Climate Change Impacts on Water Availability, Extreme Flow Events and Soil Moisture in the Goulburn and Ovens Basins, Victoria." Climate Change 34 (3-4): 513-46. Available at: HYPERLINK http://www.springerlink.com/content/j8511w54665j17n6/; http://www.springerlink.com/content/j8511w54665j17n6/ [Accessed 20 March 2012].

[25] Murphy, B. F., and Timbal, B. 2008. "A Review of Recent Climate Variability and Climate Change in Southeastern Australia." International Journal of Climatology 28 (7): 859-79. Available at: HYPERLINK http://onlinelibrary.wiley.com/doi/10.1002/joc.1627/abstr act;

http://onlinelibrary.wiley.com/doi/10.1002/joc.1627/abstr act [Accessed 19 March 2012].

[26] Bates, B. C. et al. 2008. "Key Findings from the Indian Ocean Climate Initiative and Their Impact on Policy Development in Australia." Climate Change 89 (3-4) (Special Topic: The Stern Review Debate): 339-54. Available at: HYPERLINK http://www.springerlink.com/content/926058287142120h/; http://www.springerlink.com/content/926058287142120h/ [Accessed 21 March 2012].

[27] Cai, W., and Cowan, T. 2008. "Evidence of Impacts from Rising Temperature on Inflows to the Murray-Darling Basin." Geophysical Research Letters 35 (L07701): 5. Available at: HYPERLINK http://www.agu.org/pubs/crossref/2008/2008GL033390.s html;

http://www.agu.org/pubs/crossref/2008/2008GL033390.s html [Accessed 23 March 2012].

[28] Austin, J. et al. 2010. "Climate Change Impact on Water and Salt Balances: An Assessment of the Impact of Climate Change on Catchment Salt and Water Balances in the Murray-Darling Basin, Australia." Climate Change 100 (3-4): 607-31. Available at: HYPERLINK http:// www.springerlink.com/content/308768089282164p/; http://www.springerlink.com/content/308768089282164p / [Accessed 23 March 2012].

[29] Quiggin, J., Adamson, D., Chambers, S., and Schrobback, P. 2010. "Climate Change, Uncertainty, and Adaptation: The Case of Irrigated Agriculture in the Murray-Darling Basin in Australia." Canadian Journal of Agricultural Economics 58 (4): 531-54. Available at: HYPERLINK http://onlinelibrary.wiley.com/doi/10.1111/j.1744-7976.2 010.01200.x/abstract;jsessionid=EDBF3D0913EE2D3F0 6B4F6BF7244FFD6.d03t03?userIsAuthenticated=false\& 


\section{Research Methods and Findings with Special Reference to Australia}

deniedAccessCustomisedMessage $=$;

http://onlinelibrary.wiley.com/doi/10.1111/j.1744-7976.2

010.01200.x/abstract;jsessionid=EDBF3D0913EE2D3F0

6B4F6BF7244FFD6.d03t03? userIsAuthenticated=false \& deniedAccessCustomisedMessage $=[$ Accessed 26 March 2012].

[30] Nielsen, D. L., and Brock, M. A. 2009. "Modified Water Regime and Salinity as a Consequence of Climate Change: Prospects for Wetlands of Southern Australia." Climate Change 95 (3-4): 523-33. Available at: HYPERLINK

http://www.springerlink.com/content/y325p12768u1265j/; http://www.springerlink.com/content/y325p12768u1265j/ [Accessed 26 March 2012].

[31] Barron, O. et al. 2012. "Climate Change Effects on Water-Dependent Ecosystems in South-Western Australia." Journal of Hydrology, in press. Available at: HYPERLINK

http://www.sciencedirect.com/science/article/pii/S002216 9412001412;

http://www.sciencedirect.com/science/article/pii/S002216 9412001412 [Accessed 27 March 2012].

[32] Léger, L. et al. 2011. Kakadu Vulnerability to Climate Change Impacts. Report. Department of Climate Change and Energy Efficiency, Government of Australia.

[33] Silberstein, R. P. et al. 2012. "Climatechange and Runoff in South-Western Australia." Journal of Hydrology, in press. Available at: HYPERLINK http://www.sciencedirect.com/science/article/pii/S002216 9412001072;

http://www.sciencedirect.com/science/article/pii/S002216 9412001072 [Accessed 27 March 2012].

[34] Lough, J. M., and Hobday, A. J. 2011. "Observed Climate Change in Australian Marine and Freshwater Environments." Marine and Freshwater Research 62 (9): 984-99. Available at: HYPERLINK http://www.publish.csiro.au/?paper=MF10272; http://www.publish.csiro.au/?paper=MF10272 [Accessed 27 March 2012]

[35] Mcalpine, C. A. et al. 2009. "A Continent under Stress: Interactions, Feedbacks and Risks Associated with Impact of Modified Land Cover on Australia's Climate." Global Change Biology 15 (9): 2206-23. Available at: HYPERLINK

http://onlinelibrary.wiley.com/doi/10.1111/j.1365-2486.2 009.01939.x/full;

http:/onlinelibrary.wiley.com/doi/10.1111/j.1365-2486.2 009.01939.x/full [Accessed 27 March 2012].

[36] Crase, L. 2008. "Water Policy in Australia: The Impact of Change and Uncertainty." In Water Policy in Australia: The Impact of Change and Uncertainty. Resource for the Future, edited by L. Crase. 